Vox Patrum 6/1986/z.10

\title{
PROBLEM DEFINICJI WIARY W „DYWANACH” KLEMENSA ALEKSANDRYJSKIEGO
}

Dzieło Klemensa z Aleksandrii $\Sigma \tau \rho \omega \mu \alpha \tau \varepsilon \tau_{S}$ ma charakter filozoficzno-teologiczny $i$ obejmuje osiem ksiagg ${ }^{1}$. Autor porównuje je do ogrodu ${ }^{2}$, łąki obfitującej w przerózne zioła ${ }^{3}$, oraz góry zacienionej drzewami ${ }^{4}$. Obowiązuje w nim zasada misteryjności wykładu 1 brak jasnośc1: "Zdarzy sį̧, że moje dzieło o czymś tylko napomknie, o czymś innym powie szerzej, niekiedy będzie to lakoniczna wzmianka, niekiedy spróbuje coś powiedzié między wierszaini, ukrywając coś będzie odkrywać i przemilczajł̨c będzie tym mocniej wyjawiać" 5 . Ze wzglądu na obraną metodę wykładu sam klemens ocenia swe dzieło jako trudne ${ }^{6}$, a tezę tę potwierdzaja w całej rozciagłości badacze "Dywanówn7 w zwlązku z powyższym w nlniejszych badaniach posłużono się metodą strukturalnzi $i$ przy jej pomocy zanalizowano zespó $ł$ semantyczny $\pi$ lơ ıs /obejmujący rzeczownik, czasornik, przymiotnik, przysłówek, adiectivum verbale oraz złożenia: $\eta{ }^{\circ} \& \iota \sigma \tau l \alpha, \eta \delta v \sigma \pi \iota \sigma \tau l \alpha$ oraz

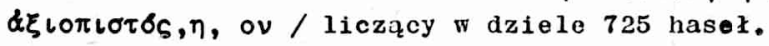

Przebadany materiał semantyczny wskazuje na to, ze Klemens definiuje $\pi l \sigma \tau \iota \varsigma$ w trojaki sposób: 1. przez ukazanie relacji wiary do innych wartości; 2. przez ukazanie jej opozycj1 do innych wartośc1; 3. podając dwie definicje wiary w znaczeniu podstawowym 1 dwie w znaczeniu religijnym.

1 Stromateis, ed. Otto Stanlin, neubearb. L.Fruchtel, Stromata, Buch I-VI, 3 Aufl., Berlin $1960=\operatorname{GCS} 15+$ Stromata, Buch VIIVIII, 2 Aufl., Beriin $1970=$ GCS $17 \mathrm{a}$.

2 Stromateis VII 111, 1-2, GCS $17 \mathrm{a}, 78-79$.

3 Tamże, VI 2,2, GCS 15,423.

4 Tanże, VII 111,1 , GCS $17 \mathrm{a}, 78$.

5 Tamże, I 15,1, GCS 15,11.

6 Tamze, VII $110,4, \operatorname{GCS} 17 \mathrm{a}, 78$.

7 Por. E.Molland, The Conception of the Gosijel in the Alexandrian Theology, Oslo 1938, 5 . 


\section{RELACJE WIARY DO INNYCH WARTOSCI}

1. Spośród relacji $\pi$ lơ ls do innych wartości na plan pierwszy wysuwaja się relacje z kręgu intelektualistycznych. Począwszy od pierwszej księgi dzieła aż po ostatnią, majż one charalster priorytetowy. Obok kwestii gnozy, którą Klemens zajmuje się w sposób szczególny, również 1 inne wartości z kręgu intelektualistycznych, jak: prawda, wiedza, poznanie, filozofia czy kerygmat zajmuja w strukturze myślowej dzleła pozycje pierwszoplanową: Wynika to zapowne $z$ jednej strony z głębokiego powiłzania umysłowości Klemensa $z$ kulturą helleńskz, a z drugiej z faktu, iż dzieło było adresowane do ludzi, którzy wyrośli na podłożu grecko-rzymskiej myśli filozoficznej. Nie dziwi nas przeto spostrzeżenie, iź autor, ukazując drogi prowadzzce do wiary, na plan pierwszy wysuwa przesłanki typu intelektualistycznego, których dostarcza filozofia i kerygmat, a dalej podając definicje wiary także najpierw mówi w niej o kwestiach natury rozumowej, a dopiero na końcu umieszcza racje inne. Podobnie w analizie aktu wiary w "Dywanie" piątym oraz w próbach specyfikacji wiary 1 gnozy w "Dywante" szóstym 1 siódmym, na plan plerwszy wybijają się treści o charakterze intelektualistycznym.

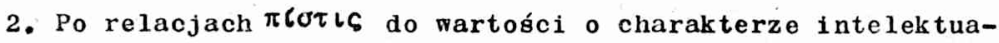
listycznym na planie drugim, w badanym polu semantycznym, plasuja się wartości z kręgu aretologicznych, a więc relacje wiary do miłości, bojaźni 1 nadzie1. Wartości te wchodzą w ramy drugiej paidei, paidei chrześcijańskiej.

Kwestie $\eta \not \gamma d \pi \eta$ u Klemensa Aleksandxyjskiego zbadał szczegółowo F.Drączkowski w pracy zatytułowanej: "Kościół-Agape według Klemensa Aleksandryjskiego" 8 . W części pierwszej omówił jej miejsce wóród innych wartości, jej istotę, funkcje 1 cechy. Uogólniając szczegółowe wywody autora naleźy powiedzieć, że o ile wiara w rozumieniu Klemensa jest matką cnót ${ }^{9}$, o tyle miłość jest najwyższą

8 F.Draczkowski, Kościół-Agape według Klemensa Aleksandryjskiego, Lublin 1983.

9 Por. A.Brontesi, La soteria in Clemente Alessandrino, Foma 1972, 
z nich ${ }^{10}$, a cały proces doskonalenia chrześcijańskiego jest procesem wzrostu 1 rozwoju agape. Melację wiary 1 nadziel ujmuje klemens krótko, lecz wyraziście. Nadzieja rodzi się, jego zdaniem, z wiary na skutek pamięci o karze 1 nagrodzie pośmiertnej ${ }^{11}$, lecz 1 odwrotnie, nadzieja stanowi impuls kierujący niewierzącego ku wie$\mathrm{rze}^{12}$. Związek wiary $i$ nadziei jest organiczny 1 pełny ${ }^{13} 1$ ma cha-

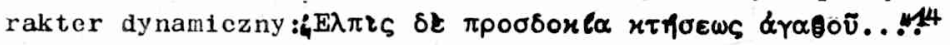

Obydwie cnoty pozostając ze sobz w ścisłej łącznośc1 prowadzą człowieka do udosionalonia moralnego, a w ostatecznym rezultacie, do osiagnięcia zbawienia. Szczegółowa analiza całości wywodów Klemensa na temat relacji wiary $i$ bojaźni prowadzi do ostatecznego.wniosku, iź wiare w procesie uwierzenia stawia nasz autor wcześniej niż bojaźń. O ile wartości z kręgu intelektualistycznych tj. prawda, wiedza, poznanie, filozofia, mądrość i kerygmat prowadzą na drogę wiary, o tyle wartości z kragu aretologicznych tj. miłość, nadzieja i bojaźń wpływaja na jej rozwój. Ujęcie problemu przez Klemensa jest więc na wskroś personalistyczne i całościowe, a posadzanie go o intelektualizm etyczny mija sie z obiektywna prawdą ${ }^{15}$.

W systemie etycznym naszego autora znaczaca rolę odgrywa ponadto $\uparrow \mathfrak{\&} \pi d \theta \varepsilon \iota \alpha$, rozumiana jednak nie na sposób stoicki, jako środek prowadzący do szczęścia, lecz jako postawa umysłu 1 woli, nie podlegająca zmianom $i$ będąca konsekwencją przyjęcia istnienia Absolutu jako najwyższego dobra ${ }^{16}$. Pełni ona także funkcja przygotowawcza

520: "Clemente Alessandrino afferma che le virtú elencate sono senz'altro figlio della fede. Questa concezione e in linea con la glorificazione della fede di Stromate II-e con loffermazione specifica già posta precedentemente, della fede come madre delle virtú" .

10 Por. I Cor 13,13; Origenes, Scholia in Canticum Canticorum 7 ; Methodius, Symosium vel convivium virginum 9,4 ; Joannes Chrysostomus, In Pentecosten hom. 2,3; idem, In epistolam II ad Corinthios hon. 30,1; Augustinus, In epistolam I Joannis hom. 9,4, 17-21; Leo, Sermones $48,79,80,88$.

11 Stromateis II 27,1 , GCS 15,127 .

12 Tanże, II 31,1 , GCS 15,129 .

13 Tanże, II 45,1 , GCS 15,136 .

14 Tamże, II 27,2 , GCS $15,127$.

15 M.Spanneut, Le'stoîcisme des Pères de l'Eglise, Paris 1957, 247248 .

16 Stromateis VII $71,3, \operatorname{GCS} 15,467$; por. G. Békés, De continua orat1one Clementis Alexandrini doctrina, Roma 1942, 68: "Haec est pro- 
w stosunku do agape, przez likwidacje namiętnosci ${ }^{17}$. Wspomniane tu ponadto dwie wartości cechują przede wszystkim prawdziwego gnosty$k^{18}$ i prowadzą chrześcijanina do apodobntenia się do Stwórcy ${ }^{19}$. Według H.I.Marrou ta idea stanowi fundamentalną tezę etyki klemen$\mathrm{sa}^{20}$.

3. W porómnaniu z relacjami z kręgu intelektualistycznych 1 aretologicznych, relacje wartości misteryjnych do wiary potraktował Klemeris mniej szczeg6łowo. Uwaga ta dotyczy w pierwszym rzedzie relacj1 wiary 1 laski, gdyz dwie następne relacje, tj. do Logosu 1 zbawienia pojawiają się nieco częściej na kartaoh dzieła. Poza

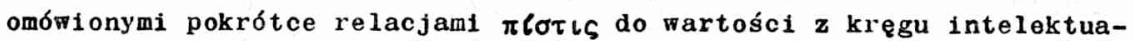
listycznych, aretologicznych $i$ misteryjnych Klemens omawia jeszcze relacje wiary do męczeństw 1 gnozy.

Według naszego autora wiara jest związana nierozerwalnie ze świadczentem. Męczeństwo zarówno jako świadectwo życia, jak równiez bwiadectwo krwi stanowi rezultat wiary, wzglednie do niej prowadzi. Najdoskonalszym świadkiem Chrystusa, w podwójnym rozumieniu tego pojęcia, jest tylko gnostyk. Siłą motoryczną 1 dynamizującą "martyriı" jest miłość obecna w duszy gnostyka, skłaniająca go do upodobnienia się z cierpiącym krwawo Chrystusem ${ }^{21}$. To ona łączy go z Bogiem 1 daje mu do Niego przystęp ${ }^{22}$. Przez nią gnostyk uzyskuje czastke siły 1 mocy Bożej 23 .

prie apatheia Clementis: excluduntur passiones concupiscibilis et Irascibilis quae affectiones corporales, partem eius intellectivam perturbantes, 1 n animam inducant".

17 Stromateis VI $71,4, \operatorname{GCS} 15,467$.

18 Por. 0.Prunet, La morale de clément d'Alexandrie et le Nouveau Testament, Paris 1966, 95 oraz E. de Faye, Etude critique des documents du gnosticisme chrétien aux 2 et 3 siècles, Paris 1925, 274.

19 Stromateis V 13,2, GGS $15,334$.

20 H.I.Marrou, Morale et spiritualité chrétiennes dans le Pédagogue Clément d'Alexandrie, StP 2/1957/538-546.

21 0.Prunet, La morale de clément, dz.cyt., 168.

22 W.Vlker, Der wahre Gnostiker nach Klemens Aleksandrinus, Berlin 1952, 503.

23 Tamże, 564. 


\section{OPOZYCJE MIETII DO INNYCH WARTOŚCI}

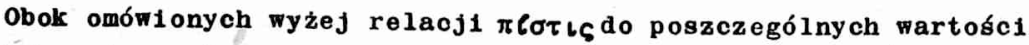
róznych kręów spełniających stotna role w definiowaniu pojęcia wiary, Klemens posługuje sie takze opozycjami. N1e sa one tak liczne jak relacje 1 trudno byłoby dopatrywad 8 ie w nich jakłejś paraleli - stosunku do omówilonych kręgów relacyjnych, niemniej jednak wydaje się, ze stanowia one waźne uzupełnienie rysowanego przez autora obrazu wiary, jakby rzucente cieni, dzięki którym obraz staje się bardzlej czytelny. Klemens zaraz na początku swego dzieła przeciwstaw1ał siq katechistom, którzy wiarę traktợali na sposób uźytíowy 1 werbalny. Jego stosunek do wiary prostaczej jest wyraźnie negatyw-

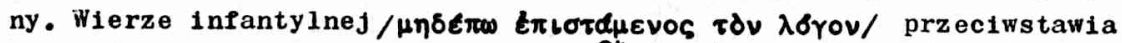

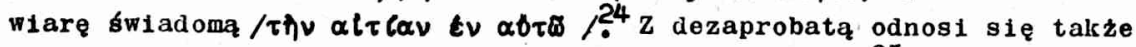
do ekstrawagancji $w$ zakresie pogląd 6 na temat wiary ${ }^{25}$. Autor nasz ocenia negatywnie zarówno postawe irracjonalno-afektywną w zakresie wiary, jak 1 zbyt daleko posunięty racjonalizm. Jako inteloktualista wysuwa na pierwszy plan prawdę, uważa ją za godną podziwu 1 przeciwstawia jej niewiare ${ }^{26}$. Kónieczność wiary do zbawienta wyprowadza z opozycji:

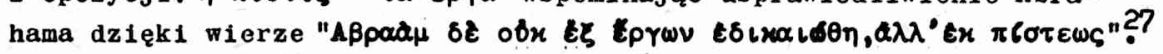

Idąc za Platonem Klemens przeciwstawia wierze w znaczeniu podstawowym brak wiedzy 1 prawdy 28 . Brak prawdy zarzuca té niewierzą-

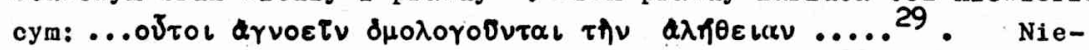
wiara zaś zawsze znajduje się w opozycji do prawdy ${ }^{30}$. Paideię pierwszą, czyli przygotowante filozoficzne człowioka do przyjęcia wiary,

24 Stromate18 I 53,3, GCS 15,34 .

25 Tamże, I 8,2 , GCS $15,6-7$.

26 Tarize, I 22,1 , GCS 15,14 .

27 Stromateis I 38,1 , GCS 15,25. Klemens powołuje sie tutaj na List Apostoła Pawła do Rzynian 4,2 .

28 Stromatois I 42, 2-4, GCS 15,28; por. Plato, Politeia III, 413 AC oraz Kriton 46 B.

29 Stromateis I 170,1 , GCS $15,105$.

30 Tamże, por. II 7,4 , GCS 15,116; II $24,3, \operatorname{GCS} 15,127$; I 38,3 , 
aczkolwiek klemens stawia wysoko, to jednak, idąc za myślą św. Pawła, przedkłada ponad mądrośé ludzkz̨ zaufanie do Boga /1 Kor 2,5; 2 Kor 1,9/. Wiara religijna stoi w opozycji do mądrości ludzkiej

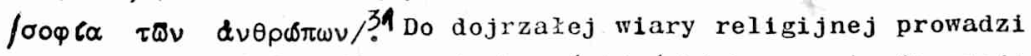
przygotowanie filozoficzne i chrześcijański kerygmat. Opozyeja pomiędzy wiarą a nieposłuszeństwem kerygmatowi chrześcijańskiemu doprowadziła do niewiary nie tylko naród żydowski ${ }^{32}$, ale także wielu ludzi wykształconych ${ }^{33}$. Posłuszeństwo zaś kerygmatowi i uleganie mu

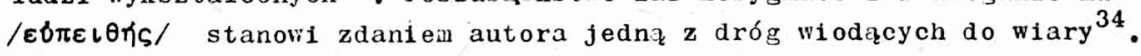
Wiara ponadto przeciwstawia siç wszelliej nieprawości etycznej

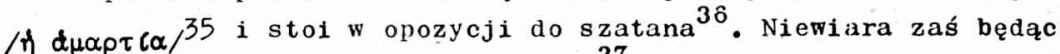
w opozycji do wolı Stwórcy $i$ nadziei ${ }^{37}$, wolności wewnętrznej i skruchy ${ }^{38}$, znajduje się także w opozycji do usprawiediiwienia ${ }^{39}$, a w konsekwencji 1 w opozycji do Chrystusa ${ }^{40}$. Szczególnie mocno $i$ wyraźnie wydobywa Klemens opozycje zachodząca pomiędzy wiarą i niewiarą. W polemice z Bazylidesem uznaje wiarę za wynik wolnego wyboru $/ \varkappa \alpha \tau \sigma \rho \theta \oplus \mu \alpha / \quad i$ w formie opozycji stwierdza, że z tego względu zasługuje ona na nagrodę ${ }^{41}$. o nagrodzie tej mówi z dużą dozą emfazy: "Wierzący posiada bogactwa całego świata - a niewierzący nie ma nawet obola" 42 .

Przejścio od niewiary do wiary odbywa się pod wpływem impulsu Bozego i stanowi pierrszy krok w kierunku zbawienia ${ }^{43}$. Pomiędzy wierzącym a niewierzacym zachodzi w rozumieniu Klemensa tak zdecydowana różnica, jak pomiędzy światłem a ciemnością, pomiędzy bóstwem

GCS 15, 133; III 85,1, GCS 15,235; V 78,3, GCS 15, 377-378.

31 Tamże, I 50,3, GCS 15,33.

32 Tainże, I 88,4 , GCS 15,57 .

33 Tamże, I 89,1, GCS 15,57 .

34 Tamże, I $88,5-7$, GCS 15,57 .

35 Tamże, por. I 167,2, GCS 15,104; III 101, 1, GCS 15,242; IV 40,4, GCS 15,266 .

36 Tamże, IV 85,1, GCS $15,285$.

37 Tamze, IV $42,2, \operatorname{GCS} 15,267$.

38 Tamże, II $11,1-2, \operatorname{GCS} 15,118$.

39 Tanże, IV 169,4 , GCS $15,323$.

40 Tanze, por. II 12,1, GCS 15,119; IV 157,2, GCS $15,318$. 41 Stromateis II 11,1, GCS 15,118; por. ed. C.Mondésert, P.Camelot,

42 Stromateis II 22,3 , GCS 15, 124.

43 Tamże, II 31,1 , GCS 15,129 。 
prawdziwym a fałszywym. Wiara jest dyskredytacją nieriary ${ }^{44}$. Tak jak istnieje zdecydorrana opozycja pomiędzy wiara 1 niewiara, tak równiez nie ma zadnej relacji między niewiarą a męczeństwem 45 . Mówiąc o krwi męczennika używa Klemens epitetu "drogocenna"

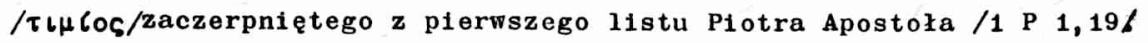
Męczenntk przelewając krew w obronie zasad wiary zawstydza niewierzących. Niewiara stoi też $w$ opozycji do zbawienia ${ }^{46}$. Według naszego autora poganie odcinając się od poznania Stwórcy, odcinają się takze od osiągnięcia zbawienia. W związku z tym ze strony chrześcijan konieczne jest prowadzenie z nimi dialogu. Dialog ten pojmuje jednak Klemens dosyć specyficznie. Według niego wszystko co.dobre 1 wartościowe w myśli starożtnej, chrześcijaństwo winno uznać za własne osiągnięcia, gdyż to wszystko pochodzi od jednego źródła prawdy, tj. od prawdziwego Boga. A więc w gruncie rzeczy nie chrześcijanie czerpią od Hellenów, lecz zachodzi stosunek odwrotny. Pogląd ten autor uścíśla jeszcze w "Dywante" szóstym przez wskazanie, iz objawienie naturalne dane poganom, było cennym darem majacym doprowadzic ich do wiary. Filozofia stanowiła dla nich substytut wia-

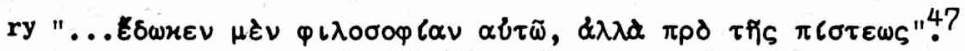

Pogante otrzymali mądrośc fllozoficzną, a Judejczycy prawo mojżeszowo welu dojśc1a do wiary 1 w zwlązku z tym, jeśli ktoś mimo wszystko nie wierzy, nie zostanie usprawiedliwiony $/ \mathrm{Rz} 1,20 ; 2,1 / 4$.

Dokonany przegląd opozycji wiary do innych wartości nasuva kilka spostrzeźeń natury ogólniejszej. Przede wszystkim naleźy zauważć, ze poprzez opozycje Klemens akcentuje bardzo dobitnie wartość wiary religijnej. Wiare $i$ ludzi wierzacych stawia bardzo wysoko, zaś brak wiary 1 ludzi niewierzących ocenta negatywnie, a nawet do pewnego stopnia piętnuje. Widać u niego pewna bezkompromisowość, charakteryzująca jego epokę. Bardzo mocno zaznacza też opozycję zachodząca między niewiarą a prawdą, a więc opozycję w kręgu wartości

44 Tamże, IV 80,3, GCS $15,283$.

45 Tamze, IV 13,3, GCS $15,254$.

46 Tamze, $v 19,1, \operatorname{GCS} 15,338$.

47 Tamze, VI 110,3, GCS $15,487$.

48 Tamze, v 11,2, GCS 15,332 . 
- charakterze intelektualistycznym. Za pomocz opozycji Pormułuje też swój pogląd na temat czynników prowadzących do wiary. Sa nimi f1lozofia, kerygme.t, elementy mistyczne 1 wartości moralne. Wszystkie te wartości znajdują się w spozycji do niewiary. Boski Logos uważa Klemens za ostateczny ct - wiary, a misję soteriologiczna Chrystusa ujmuje na wskroś uniwersalistycznie. Poprzez wprowadzenie do wykładu opozycji, obraz wiary i człowiek arzzcego został skonkretyzowany, doprecyzowany i niejako wycieniowany.

\section{PROBY DEFINICJI WIARY}

Klemens, zgodnie ze swoim założeniem generalnym powzięty is na początku "Dywanów" ${ }^{49}$ i powtórzonym kilkakrotnie później ${ }^{50}$, nie dePiniuje pojęcia wiary zaraz na początku swoich rozważań ani nie podaje jednej wyczerpującej definicji, lecz posługuje się przede wszystkin forma relacji 1 opozycji, a dopiero na dalszym planie swojego dzieła zamieszcza próby definicji. Tego rodzaju postawa piRarska wypływa zapewne nie tylko z zasad oboviazujących w jego czasach 1 z indywidualnych upodobań, lecz także została w dużym stopniu podyktowana trudnością tematu ${ }^{51}$. Popatrzmy na próbę zdefiniowania wiary najplerw w znaczeniu podstawowym, a nastepnie w znaczeniu religijnym.

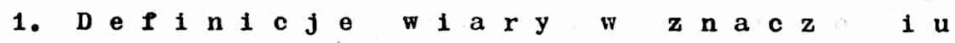
pods t a w o w y m. W "Dywanien drugim Klenens określa wiarę

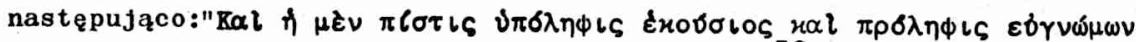

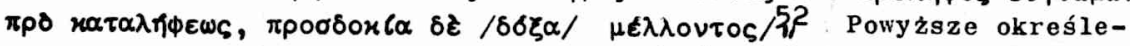

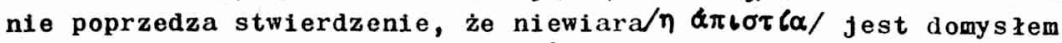

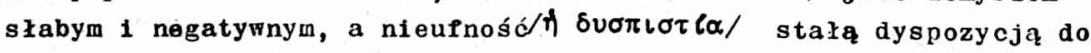
niedowierzania. W przytoczonej definicji wiary posługuje siz autor

49 Tanie, I 15,1, GCS $15,11$.

50 Tamże, por. ví $2,1, \operatorname{GCS} 15,422-423$; VII 111, $1, \operatorname{GCS} 17 a ̆, 78$.

51 Por. F.Moland, The Conception of the Gospel, dz.cyt., 5 .

52 Stromateis II 28,1, GCS 15, 128: "Wiara jest to przypuszczenie dobrowolnie powzięte $i$ rozważe, sąd wstępny przed aktem czysto poznawczym". 


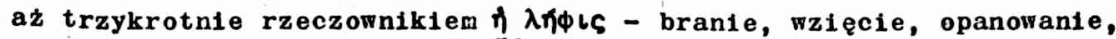
zabr. $n$, otrzymanie, ząanie ${ }^{53}$, modyeikujac go przedrostkiem

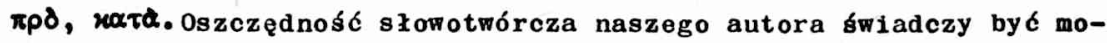
ze o usilnym dązeniu do ścisłości terminologicznej i stąd pochodzi chę ó oparcia swych sformułowań o najwyższe autorytety filozoficzne starozytnośc1, względnie stanowi odbicie stopnia trudności z jakimi sie Klemens borykał. Przedstawiona definicja składa się z trzech członów: a/ wiara jest przypuszczeniem dobrowolnym/tnoбoடos/,

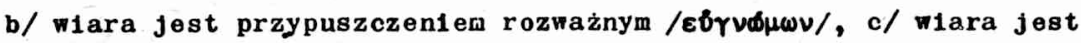
przypuszczeniem wstępym / $\pi \rho \delta \delta 6 \xi \alpha \mu \epsilon \lambda \lambda \circ \nu \tau o \zeta /$. Wiarę więc w znaczeniu podstawowym charakteryzują trzy bardzo wazne cechy: dobrowolność, rozwaga 1 charakter wstępny. Poprzedzając omawianą definicje wiary określeniem nlewiary docaje Klemens od strony negatywnej jeszcze dule cechy wiary, tj. zaangazowanie 1 chara'. er pozytywny. Trzy spoáród wymienionych cch wiary, tj. dobrowolnosć, rozwaga 1 zaangażomanie definiują ja od strony podmiotowej, zaś dwie pozostałe, ${ }^{+} j$. jej charakter wstępny $i$ walor pozytywny stanowią próbę przedmiotowego 1 obiektywnego spojrzenia na definiowane pojęcie. W spojrzeniu podmiotowym na pojecie wia y uwględniony został obok elementu intolektualnego takze 1 czynnik wolitywny. Aspekt przedmiotowy wiary, wyrazajacy sie w jej charakterze introdukcyjnym w stosunku do innych wartości 1 w charakterze pozytywnym,otrzymał juz wcześniejszą aprobate Klemensa, zawartą we wcześniej zamieszczonej polenice z Heraklitem 1 Pit agorasem 54 .

Obok przedstawionej wyżej definicji wi v wnaczeniu podstawowym, podaje Klemens $w$ "Dywante" czwartym Jo_ze jedno określenie - charakterze ontologicznym。 oto niejako na marginesie etymologi-

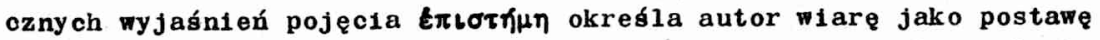

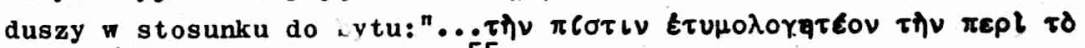

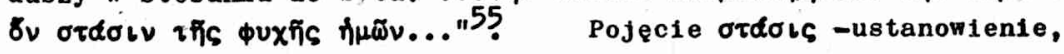

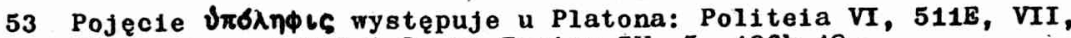
534A oraz $u$ Arystotelesa: Topica IV, 5, 126b 18 .

54 Stromate13 II $24,3-5$, GCS 15, 125-126.

55 Tamze, IV 143,2, GCS 15,311. 
stanie, stan, położenie - kładzie klemens jako podwalinę swej drugiej definicji wiary w znaczeniu podstawowym ${ }^{56}$. Porównujac defintcję niniejszą z określeniem wiary zamieszczonym w "Dywanie" drugim, należy powiedzieć, że o lle tamta ma charakter podmiotowo-rzeczowy, merytorycznie dopracowany $i$ ścisły, o tyle powyżsa ma charakter czysto formalny $i$ stanowi dopowiedzenie do poprzedniej. Niemniej. Jednak to dopowiedzenie, $z$ punktu całościowego spojrzenia na wiarę, jest bardzo ważne, gdyż dodaje do wymienionych wcześniej pięolu cech wiary jeszcze jedna, tj. Fymiar ontologiczny. Analiza niniejszej kwestii wskazuje raz jeszcze na to, iz postawę pisarską Klemensa cechuje uniwersalizm $i$ progresywizm. Autor nie poprzestaje na ukazaniu relacji, opozycji i jednej tylko próbie podania definicji wiary, ale drąży omawiany problen wszechstronnie $i$ dostrzega nowe aspekty omawianej rzeczywistości. Nidoczny jest w tym ponadto pewien niepoló́j twórczy $i$ dynamizm autora wyrażający siž w jego zaangaźowaniu w omawiany problem $i$ chęć wyśwletlenia go do końca. Chociaz zasadniczo cholzi mu w dziele o wyjaśnienie kwestil wiary religijnej, to jednak usiłuje także $i$ pojęcie wiary w znaczeniu podstawowym podać możliwie jak najbardziej precyzyjnie. Zespóz semantyczny $\pi l \sigma \tau \iota \varsigma$ w swej formie definiujazcej osiagga w tym momencie punkt szczytowy, kulminacyjny, gdyż służy bezpośrednio określeniu i poznaniu istoty wiary.

$$
\text { 2. Definic je wiary w z na c ze n i u }
$$

r e l i g $\mathbf{i}$ j n y m. Pierwsza próbę określenia wiary w znaczeniu religijny zamieścił Klemens na początku "Dywanu" drugiego: "Wiara jest d৮browolną akceptacją wstępną /tj. wyprzedzającą doświadczenie/, jest potwierdzeniem uczucia religijnego $w$ odniesieniu do bóstwa, jest zastępczym wyobrażeniem tego, czego się spodziewamy, oraz doświadczalnylm sprawdzianem rzeczy, których zobaczyć nie można". Dzięki niej przede wszystkim "przodkowie /nasi/ uzyskali świadectwo uznania.

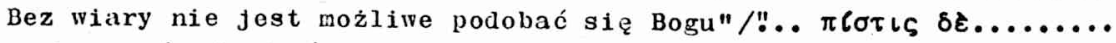

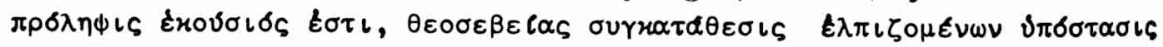

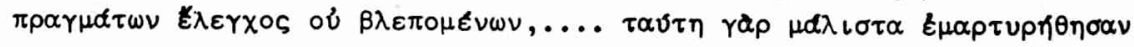

56 Por. Słownik grecko-polski, red. Z. Abramowiczówna, IV, Warszawa 1965,$96 ;$ Greek-English Lexicon, red. H.G.Liddell' - R.'Scott,
Oxford 19589, 1634. 


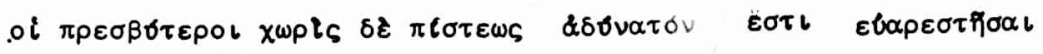
$\varepsilon \bowtie$........ $/ 57$

Przytoczona in extenso definicja składa sizz z dwóch członów: 1/ wstępnego, pochodzł̧cego od Klemensa $i$ będącego zmodyfikowanym powtórzeniem definicji wiary w znaczeniu podstawowym, oraz $2 /$ zasadniczego - będącego przytoczeniem definicji wiary z Listu do Hebrajczyków /Hbr 11,1 - 2 i 6/. Klemens ujmuje wiarę religijną w aspekcie egzystencjalnym jako pewien proces, który cechuje: 1/ dobrowolność, 2/ rozwaga, 3/ charakter wstępny. Są to więc elenenty te same, które zawiera takźe definicja wiary w znaczeniu podstawowym ${ }^{58}$. Autor ponadto posługuje się tu tym samym platońsko-arystotelesorskim

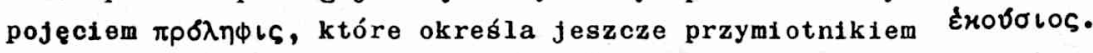
Rozumności aktu wiary 1 jego charakteru introdukcyjnego nie vydoby-

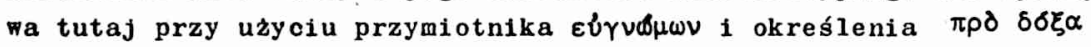

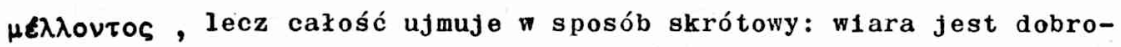
wolną akceptacja wstępną. Do tego, w zasadzie powtarzającego sią okré́lenia wiary, dołacza autor specyfikacje religijną: wiara jest potwierdzeniem uczucia religijnego w odniesieniu do bóstwa /

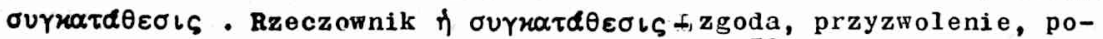
twierdzenie - posiada tutaj znaczenie istotne ${ }^{59}$. Chodzi tu nie tylko - zgodę w znaczeniu intelektualnym, lecz o pełną akceptację istnienia Boga także w sferze wolitywnej $i$ afektywnej, a więc w wymiarze personalistycznym. Tę właśnie definicję o charakterze podmiotowym uzupełnia Klemens jeszcze określeniem wiary, które cytuje dosłownie z listu do Hebrajczyków /11, 1-2 i 6/. Pierwszy człon definicji ujmuje wiare od strony przedmiotowej, drugi zaś ma charakter klauzuli pochwalnej. Istota wiary jest więc to, że stanowi ona wyobrażenie

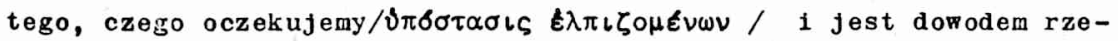

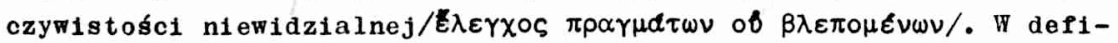

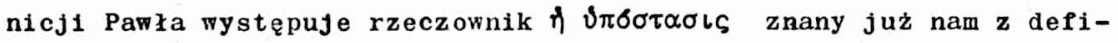
nicji wiary w znaczeniu podstawowym podanej przez Klemensa oraz rze-

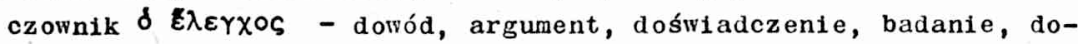

57 Stromateis II 8,4 , GCS 15,117 .

58 Tamże, por. II 28,1 , GCS 15,128 .

59 Por. Abramowi cz6wna IV, 132; Liddell-Scott 1663. 
ciekanie ${ }^{60}$. Ostatni człon omawianej definicji wiary, będący takze tekstem z listu do Hebrajczyków, zawiera pochrałe wiary religijnej.

Przedstawiona wyżej definicja wiary religijnej, składająca się z dwóch członów, tj. z definłcji klemensa 1 definicji Pawła, zawiera trzy części, a mianowicie: definicję podmiotową, przedmiotową 1 klauzulę pochwalną. Podmtotem wiary jest człowiek obdarzony rozumem, wolną wolą 1 uczuciami. Klemens pomimo swych znanych skłonnó́ci intelektualistycznych ujmuje podmiot wiary, tjo'człowieka. całościowo we wszystkich wymiarach jego osobowośc1. Przedmiot wiary stanowi Bóg - Absolut, którego człowiek na ziemi nie moze poznać w sposób bezpośredni 1 doświadczalny. Wiara w rozumieniu Klemensa jest łacznikiem pomiędzy tymi dwiema rzeczywistościami, tJ. między '́wiatem' widzialnym $i$ nieridzialnym, między człowiekiem a Absolutem. Z tej szczególnej lunkcji wiary płynie jej niezwykła wartośc zasługująca na pochwałe.

Podobnie, jak w odniesieniu do wiary w znaczenlu podstawowym podaje nasz autor dwie definicje, tak 1 w przypadku wiary religij-

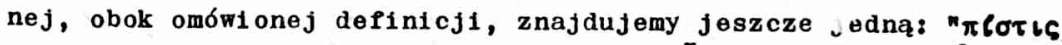

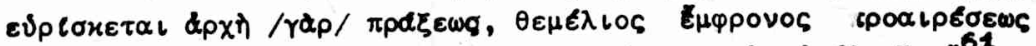

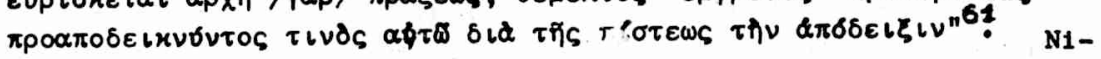
niejsza definicja zdradza wyraźnie pokrewienstwo z myśla Arystotele$\mathrm{sa}^{62}$. Obok elementów wymienionych w poprzedniej definicji wiary religijnej ${ }^{63}$, oraz w definicjach wa ar waczeniu podstawowym ${ }^{64}$, dochodzi tutaj jeszcze jeden czynnik typowy dla myśli arystotelesorskiej, tj. działanie/t $\pi \rho \downarrow \zeta \zeta \iota s /$.

Poprzez dodanie do wymienionych już podmiotowych coch wiary, tj. dobrowolności, rozumności 1 charakteru wstępnego oraz cechy przedmlotowej jaką jest jej związei z Absolutem, Jeszcze nowej ce. chy w postaci działania, nadaje klemens wierze religijnej wymiar dynamiczny. W takim ujęciu wiara praestuje byé rzeczywistością bierną,

60 Dor. Abramow1 czówna II, 98; Liddell-Scott 530.

61 Stromateis II 9,2, GCS 15,117: "Wlara mus jyc początk1em dz1alania $i$ samą bazą wyboru umysłowego, wyprzodzającego za jej pośrednictwem potwierdzenie doświcczaine czegos przed samym sobą".

62 Por. Etyka Nikomachejska 6,2 , 1139b 4 oraz 1139a 31.

63 Stromateis II 8,2 , GCS 15,117 .

64 Tamze, Ii 28,1 , GCS 15,128 iv 143,2 , GCS 15,311 . 
statyczna, abstrakcyjng, lecz ujawnia się jako rzeczywistośc dynamiczna, aktymna w stosunku do otoczenia $i$ bardzo konkretna, pomimo swego niematerialnego charakteru. Zycie, działanie 1 postępowanie zgodne z zasadami wyznawanej przez sieble wiary, stanowiło 1stotny element pragmatyki postepowania pierwszych chrześcijan. Potwierdzają to w całej rozciagłości Dzieje Apostolskie 1 Listy, a w szczególności Liøt Jakuba Apostoła. Interesujący jest rakt, ze Klemens w swej drugiej definicji wiary religijnej nie siega do wspomnianych tekstów biblijnych, lecz powołuje się na najwyższy autorytet filozoficzny świata starozytnego, tj. na Arystotelesa. Być może, ze chodziło-mu o uzyskanie pewnego paralelizmu w stosunku do mýlli Pawłowej, o którq oparł swą definicję pierwsza, względnie - latwiejsze pozyskante dla chrześcijaństwa 6wczesnej elity umysłowej, będącej przecieź pod przemoźnym wpływem Pllozofil greckiej. Klemens jako eklektyk wyraźnie odrzuca filozofię Ep1kura 1 Demokryta $^{65}$ nadaje nowe znaczenie stoickiemu pojęciu cnoty ${ }^{66} 1 \mathrm{z}$ pezną świado ó́cią aprobuje te wartości, które zbieżne są z chrześciJaństwem. Swiadomie tez nawiazuje do tych wartości, które dobrze sa znane jego czytelnikom. Podane przez Klemensa definicje miary wskazują $i$ na to, że w sprawach najważniejszej wagi opiera sie w E.ch sformułowaniach o autorytety najwyższego rzędu, a analizowany problen pragnie zbadać wszechstronnie 1 do końca. W efekcie takiej postawy pisarskiej, dzięki zastosowaniu różorodnych form wyrazu, czytelnik uzyskuje pełny 1 wyczerpujacy obraz omawianej kwest11.

$$
\text { Ks. Henryk 0strowsk1 - Lublin }
$$

DE PROBLEA4TE DEFINITIONIS FIDEI IN "STROMATEIS" CLBMENTIS ALEXANDRINI /Summarium/

In articulo "De problemate definitionis Pidei in $\Sigma \tau \rho \omega \mu \alpha \tau \varepsilon \tau_{\varsigma}$ clementis de Alexandria" haec continentur, quae methodo structurali

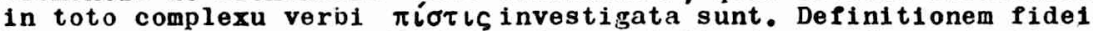
Clemens in suo opere triplici modo exprimit: 1. per demonstrationem relationum fidei ad alia elementa; 2. per demonstrationem eius op-

65 Stromate1s I 50,6 , GCS 15,$33 ;$ I 52,1 , GCS 15,34 ; VI 67,2 , GCS 15 165; S.R.C.Lilla, Clemens of Alexandria. A Study in Christian P. conism and Gnosticism, Oxford 1971, 227 i 232.

66 F. van cier Grinten, Die nattrliche Begrtundung des Tugendlebens bei Clemens von Alexandrien, Rom-Bonn 1949, 1 i 34 . 
positionum; 3 . per definitionem fidei et in sensu fundamentali et in sensu religioso. Inter relationes fidei ad alia elementa, in toto opere clementis, a libro primo usque ad postremum, elementa intellectualia primum locum tenent. Post haec sequuntur relationes aretologicae, mysticae et aliae. Oppositiones fidei ad alia elementa quamquam non multae sunt, attamen imaginem fidei nobis perficiuntur. Per illas oppositiones clemens perspicue valorem fidei indicat, cum fides et fideles laudantur, tum infidelitas et infideles notam negativam habent. Analysis definitionum fidei in sensu fundamentali et In sensu religioso artioulum concludit. Definitiones Pidel in sensu religioso quandam analogiam ad doctrinam Paul1 Apostoll demonstrant. Insuper Imago fidel secundum clementem quodam valore activitat1s pollet, qui videtur influxus dootrinae Aristotelis esse. 